\title{
Allometric Relationships for Biomass and Carbon Estimation of Neem (Azadirachta indica A. Juss) Plantations in Dryland of Hyderabad, Telangana
}

\author{
M. B. Noor mohamed ${ }^{1 *}$, G. Rajeshwar Rao ${ }^{2}$, Keerthika A. ${ }^{3}$, Dipak Kumar Gupta ${ }^{4}$ and A. K. Shukla ${ }^{5}$ \\ ${ }^{1,3,4,5}$ Central Arid Zone Research Institute (CAZRI), Regional Research Station, Pali-Marwar, Rajasthan (306 401), India \\ ${ }^{2}$ Central Research Institute for Dryland Agriculture (CRIDA), Hyderabad, Telangana (500 059), India
}

\section{Corresponding Author}

M. B. Noor mohamed

e-mail: mohamedforester@gmail.com

\author{
Article History \\ Article ID: 3C0526a \\ Received in $16^{\text {th }}$ October, 2017 \\ Received in revised form $15^{\text {th }}$ January, 2018 \\ Accepted in final form $02^{\text {nd }}$ February, 2018
}

\begin{abstract}
The present study was conducted in Central Research Institute for Dryland Agriculture (CRIDA), Hyderabad to develop the allometric equations for predicting the total biomass and carbon of Azadirachta indica in three different basal diameter classes $(0-10 \mathrm{~cm}, 10-20 \mathrm{~cm}$ and $20-30 \mathrm{~cm})$. The growth variables viz., tree height, basal diameter, $\mathrm{DBH}$, crown height and crown width are maximum for neem under higher diameter class, whereas minimum under lower diameter class. The average total biomass of neem tree was recorded as $122.3 \mathrm{~kg} / \mathrm{tree}$ and $338.8 \mathrm{t} /$ ha in all three diameter classes. The allometric relationship between the variables in Azadirachta indica was highly significant with positive and high correlation. The highest and significant linear relationship was observed in tree height (0.992) followed by crown height (0.963) with above ground biomass. With below ground biomass, a strong and highly significant relationship was observed in tree height (0.988) followed by crown height (0.974) and DBH (0.967). The above ground variables (tree height, basal diameter, DBH, crown height and crown width) had highly significant linear relationship with predicted variable of total biomass. The highest and strongest coefficient observed between total carbon and tree height (0.991) followed by crown height (0.968) and DBH (0.957). And also, the significant relationship was found between the dependent variable (total carbon) and other independent variables viz., basal diameter (0.821), and crown width (0.910). Therefore, the result of this study may be useful to predict the amount of total carbon and biomass stored in Azadirachta indica plantation on area basis.
\end{abstract}

Keywords: Allometric equations, Azadirachta indica, Biomass, Total carbon

\section{Introduction}

Neem (Azadirachta indica) commonly called 'Indian Lilac' or 'Margosa', belongs to the family Meliaceae,subfamily Meloideae and tribe Melieae. Neem is the most versatile, multifarious trees of tropics, with immense potential. It possesses maximum usefulnon-wood products (leaves, bark, flowers, fruits,seed, gum, oil and neem cake) than any other treespecies. It has been used in Ayurvedic medicine for more than $\mathbf{4 0 0 0}$ years due to its medicinal properties. It is a tropical evergreen tree (deciduous in drier areas) native to Indian sub-continent (Anonymous, 1985; Roxburgh, 1874). Neem is a large tree growing about $25 \mathrm{~m}$ in height with semi-straight to straight trunk, $3 \mathrm{~m}$ in girth and spreading branches forming a broad crown. It thrives well in dry, stony shallow soils and even on soils having hard calcareous or clay pan, at a shallow depth (Anonymous., 2006; Girish and Shankara Bhat, 2008). The tree grows naturally in areas where the rainfall is in the range of 450 to $1200 \mathrm{~mm}$. However, it has been introduced successfully even in areas where the rainfall is as low as 150 to
$250 \mathrm{~mm}$. Neem grows on altitudes up to $1500 \mathrm{~m}$ (Chari, 1996 and Tewari, 1992). It can grow well in wide temperature range of $0{ }^{\circ} \mathrm{C}$ to $49^{\circ} \mathrm{C}$ (Hegde, 1995). The $\mathrm{pH}$ range for the growth of neem tree lies in between 4 to 10 . It grows on almost all types of soil including clayey, saline and alkaline soil, but does well on black cotton soils and deep well drained soil with good sub-soil water (Hegde, 1995).

Trees are recognized as a possible carbon reservoir, and as carbon dioxide concentrations increase in the atmosphere, precise and convenient methods for forest biomass estimation are needed. Though there are several ways to determine biomass of plants in forests, two main approaches are commonly used. These are destructive harvesting of the plants and then determining their biomass, and the use of allometric equations to predict biomass of plants. However, it is preferable that allometric equations are mostly used to estimate tree and forest biomass without destruction. Allometry is the most common approach of estimating growth and biomass of individual tree, plantation and forests. 
Allometric equations are most widely used method for estimating biomass and carbon of plantations and forests. They are developed and applied to forest inventory data to assess the biomass and carbon stocks of plantations and forests. The allometric equations for biomass estimation are developed by establishing a relationship between the various physical parameters of the trees such as the $\mathrm{DBH}$, total height of tree, height of tree trunk, crown diameter, tree species, etc. These equations are developed for single species and for mixture of species give the estimate of biomass for specific sites and for large scale global and regional comparisons.

Allometric equations are, however site specific and empirical. Equations developed here will be used for validating a two dimensional tree growth and biomass allocation model under various growing environments, without the need for destructive sampling With the help of carbon content of tree biomass, which is assumed to be fixed proportion of the biomass (Montagnini and Porras, 1998) or determined directly (Kraenzel et al., 2003), they can be used to estimate carbon storage in trees and forests (Losi et al., 2003) and their wood and foliage (Specht and West, 2003). Allometric relationships can also be used for estimating carbon fluxes (Chambers et al., 2001) and implication of large scale deforestation and carbon sequestration on carbon cycle and carbon balance (Ketterings et al., 2001), monitoring growth and partitioning of above ground interactions when trees are used for agroforestry purposes. Therefore, the study was aimed to develop allometric equations for estimation of total biomass and total carbon of Azadirachta indica plantation at dryland of Hyderabad, Telangana (India).

\section{Materials and Methods}

\subsection{Experimental site}

The experiment was carried out in Hayathanagar Research Farm (HRF) of the Central Research Institute for Dryland Agriculture, Hyderabad which is located at $17^{\circ} 27^{\prime} \mathrm{N}$ latitude, $78^{\circ} 35^{\prime}$ longitude with above mean sea level of $515 \mathrm{~m}$. The mean annual temperature of the experimental site is $13.5^{\circ}-38.6^{\circ} \mathrm{C}$ and the mean annual rainfall is $755 \mathrm{~mm}$. The experimental soil represented Alfisol soil order (Typic Haplustalf), with $\mathrm{pH}$ slightly acidic to neutral (6.4) and EC $0.085 \mathrm{dS} \mathrm{m}^{-1}$. The soils were low in available nitrogen (145 kg ha-1), medium in available phosphorus (13.0 kg P ha-1) and available potassium (175 kg ha-1). The ten-year-old Azadirachta indica plantation with $6 \times 6 \mathrm{~m}^{2}$ spacing was selected to develop allometric equation of biomass and carbon stock. The experiment was carried out during $15^{\text {th }}$ November, 2014 to $15^{\text {th }}$ February, 2015 in winter season. The carbon and biomass analysis were carried out in Soil Chemistry and Fertility Laboratory of CRIDA.

\subsection{Demarcation and enumeration for measurements}

The entire field was divided in to plots of equal size and within each plot, $25 \%$ of the trees were marked representing the population and the growth parameters of these trees were monitored at regular intervals. Trees were harvested during the months of November, 2014-February, 2015. Entire plantation was divided into three diameter classes viz, $0-10 \mathrm{~cm}, 10-20 \mathrm{~cm}$ and $20-30 \mathrm{~cm}$ for measuring the growth parameters. As the destructive sampling of the Azadirachta indica trees was very laborious and time consuming. So, three representative trees in the respective diameter class were selected for destructive sampling. Growth variables viz., tree height, basal diameter, DBH, crown height and crown width were measured before felling of trees. These measurements were recorded as per established procedure.

\subsection{Biomass estimation}

The trees were felled at ground level using a mechanical chain saw (Poulan/Pro, USA). After recording the total height and $\mathrm{DBH}$ of the felled trees, the above ground portions were separated into wood, branches and leaves. For below ground biomass estimation, pits were excavated and complete recovery of roots was done from tree base. Fresh weights of the entire above and below ground tree components were recorded immediately after felling using appropriate spring scales. A small sample (500 gram (g)) of wood, branches and leaves was immediately transferred to the laboratory in double sealed polythene bags. The collected samples were dried at $80^{\circ} \mathrm{C}$ till constant weight was obtained. The oven dry weight of the whole sample was calculated using the formula given below (Gnana Mathuram, 2009).

Dry weight of the tree biomass=(Oven dry weight of the sample/Fresh weight of the sample) $\times$ Fresh weight of the whole tree

\subsection{Allometry equation for estimation of biomass and carbon}

A good allometric equation can predict the biomass of a tree without the need for destructive sampling. A power function is generally used to predict a trees biomass from the diameter (Ghezehei et al., 2009; Acthen et al., 2010). In order to assess the tree biomass the regression equations developed by L.S. Lodhiyal (1992) have been used. In terms of biomass and carbon was estimated using simple allometric equation in the form of,

$\mathrm{Y}=\mathrm{a} \mathrm{X}^{\mathrm{b}}$

Where,

$Y$ is dry biomass and carbonof tree components

$X$ is predictor variables (Tree height, basal diameter, $\mathrm{DBH}$, crown height, crown width, etc.,)

$\mathrm{a}$ is $\mathrm{Y}$ intercept

$\mathrm{b}$ is a regression coefficient

The dry biomass may be replaced by tree dimensions such as tree height, basal diameter, $\mathrm{DBH}$, crown height and crown width. Allometric equations were developed for both total above, total below and total (above+below) dry biomass. Using logarithmic transformation on both sides.

$\log Y=b \log D+\log a$ 
Where,

$\mathrm{Y}$ is the dry biomass or carbon

$b$ is the slope

$\log a$ is the intercept of the linear equation ( $\log 10$ yields a lower sum of squares than the natural logarithm In).

$D$ is the predictor variable

The allometric relationship was established using power model between dependent and independent variables (tree height, basal diameter, DBH, crown height, crown width and biomass of tree components).A total of all the allometric relationships were developed for predicting biomass and carbon were found significant at $1 \%$ based on $F$ value. The parameters of the linearized allometric equations ( $b$ and $\log$ a) were estimated by means of linear regression using SPSS (version IBM SPSS Statistics 20). The original parameter "a" was finally computed by taking antilog function. The significance and validity of the equations developed were evaluated with the $R^{2}$ value, the F-statistic, and a scatter plot of the residuals. Microsoft Excel was used to visualize graphs of the equations.

\section{Results and Discussion}

\subsection{Growth characteristics of Azadirachta indica}

The observations on tree height, basal diameter, number of branches, DBH, crown height, crown length was recorded at various diameter classes of were given Table 1 . The growth variables viz., tree height, basal diameter, $\mathrm{DBH}$, crown height and crown width are maximum for neem under higher diameter class, whereas minimum under lower diameter class. The maximum tree height for neem was recorded as $6.750 \mathrm{~m}$ under higher diameter class, whereas minimum tree height $(4.400 \mathrm{~m})$ recorded under lower diameter class. The basal diameter was recorded maximum $(24.00 \mathrm{~cm})$ under 20-30 $\mathrm{cm}$ diameter class and minimum $(8.600 \mathrm{~cm})$ under $0-10 \mathrm{~cm}$ diameter class. At neem tree, maximum number of branches was registered in higher diameter class (44.00) and minimum in lower diameter class (14.00). The maximum $D B H$ recorded in higher diameter were $22.50 \mathrm{~cm}$ and minimum $\mathrm{DBH}$ in

Table 1: Descriptive statistics of Azardirachta indica

\begin{tabular}{|c|c|c|c|c|c|}
\hline Variable & Minimum & Maximum & Mean & SE (mean) & Std. Deviation \\
\hline Tree height (m) & 4.400 & 6.750 & 5.485 & 0.317 & 0.951 \\
\hline Basal diameter $(\mathrm{cm})$ & 8.600 & 24.00 & 16.93 & 2.112 & 6.338 \\
\hline No. of branches & 14.00 & 44.00 & 31.22 & 4.152 & 12.45 \\
\hline $\mathrm{DBH}(\mathrm{cm})$ & 8.800 & 22.50 & 15.23 & 1.860 & 5.581 \\
\hline Crown height $(m)$ & 1.000 & 2.300 & 1.586 & 0.166 & 0.498 \\
\hline Crown width (m) & 1.800 & 7.600 & 4.622 & 0.791 & 2.373 \\
\hline Leaves biomass ( $\mathrm{kg} \mathrm{plant}^{-1}$ ) & 1.200 & 4.000 & 2.511 & 0.383 & 1.149 \\
\hline Stem biomass (kg plant ${ }^{-1}$ ) & 4.000 & 36.00 & 17.03 & 4.711 & 14.13 \\
\hline Primary branch biomass (kg plant ${ }^{-1}$ ) & 6.200 & 71.00 & 31.61 & 9.853 & 29.56 \\
\hline Secondary branch biomass (kg plant ${ }^{-1}$ ) & 11.00 & 53.90 & 27.90 & 6.451 & 19.35 \\
\hline Above ground biomass (kg plant ${ }^{-1}$ ) & 24.00 & 164.0 & 79.05 & 21.37 & 64.13 \\
\hline Below ground biomass (kg plant ${ }^{-1}$ ) & 10.00 & 94.80 & 43.46 & 12.61 & 37.83 \\
\hline Total Biomass (above and below ground) $\left(\right.$ kg plant $\left.^{-1}\right)$ & 34.00 & 258.8 & 122.5 & 33.98 & 101.9 \\
\hline
\end{tabular}

lower diameter class were $8.800 \mathrm{~cm}$. Among the targeted tree species, higher diameter class was ascertained to have a maximum crown height and crown length $(2.300 \mathrm{~cm}$ and $7.600 \mathrm{~cm}$ ) and minimum in lower diameter classes (1.000 and $1.800 \mathrm{~cm}$ ). Among the targeted tree species, higher diameter class was ascertained to have a maximum growth

\subsection{Biomass production of Azadirachta indica}

Above and below ground biomass on per tree and per hectare basis (Table 2) of the selected tree species showed the same trend of biomass allocation as per biomass allocation of Azadirachta indica. The result presented on biomass production of neem indicates that biomass of neem increased with a corresponding increase in diameter class and was recorded maximum in leaf biomass $\left(3.808 \mathrm{~kg} \mathrm{tree}^{-1}\right)$, stem biomass $\left(35.75 \mathrm{~kg}^{-1} \mathrm{e}^{-1}\right)$, primary branch biomass $(70.23 \mathrm{~kg}$ tree $\left.^{-1}\right)$, secondary branch biomass (53.96 kg tree ${ }^{-1}$ ) and root biomass (93.18 kg tree ${ }^{-1}$ ) under $20-30 \mathrm{~cm}$ diameter class during 2014-15. The average total biomass of neem tree was recorded as $122.3 \mathrm{~kg}$ tree $^{-1}$. Among the fractionated plant parts, the roots were exhibited maximum average biomass (43.09 $\mathrm{kg}$ tree $^{-1}$ ) followed by primary branch biomass (31.71 $\mathrm{kg}$ tree $\left.^{-1}\right)$, secondary branch biomass (28.19 $\left.\mathrm{kg}^{\text {tree }}{ }^{-1}\right)$, stem biomass (16.81 kg tree ${ }^{-1}$ ) and leaf biomass (2.507 kg tree ${ }^{-1}$ ). The average total above ground biomass were recorded as $79.21 \mathrm{~kg} \mathrm{tree}^{-1}$ (Table 2). The reason is due to more number of branches in in higher diameter classes. The findings are in conformity with that of Singh and Lodhiyal (2009); Uma et al. (2011); Noor mohamed et al. (2016); Also, the branch biomass 


\begin{tabular}{|c|c|c|c|c|c|c|c|}
\hline Basal Dia. class & LB kg plant $^{-1}$ & SB kg plant ${ }^{-1}$ & PBB kg plant ${ }^{-1}$ & SBB kg plant ${ }^{-1}$ & AGB kg plant ${ }^{-1}$ & BGB kg plant $^{-1}$ & TB kg plant $^{-1}$ \\
\hline $0-10$ & 1.360 & 4.320 & 6.384 & 12.05 & 24.11 & 10.39 & 34.50 \\
\hline $10-20$ & 2.355 & 10.37 & 18.52 & 18.56 & 49.80 & 25.71 & 75.52 \\
\hline $20-30$ & 3.808 & 35.75 & 70.23 & 53.96 & 163.7 & 93.18 & 256.9 \\
\hline Mean & 2.507 & 16.81 & 31.71 & 28.19 & 79.21 & 43.09 & 122.3 \\
\hline
\end{tabular}

LB: Leaf biomass; SB- Stem biomass; PBB: Primary branch biomass; SBB: Secondary branch biomass; AGB: Above ground biomass; BGB: Below ground biomass; TB: Total biomass

depends upon the size of the branches and structure of large and small branch sizes in the canopy (Heriansyah et al., 2007).

\subsection{Allometry relationships between variables in Azadirachta indica}

The allometric regression was highly significant between dependent and independent variables at tree level by using power model. Allometry relationships for predicting the biomass and carbon were found significant at $1 \%$ level.

3.3.1. Allometry equation for estimating above ground biomass

The allometry regression was developed with highly significant and positive correlation coefficients. The above ground biomass had strong relationship with independent variable such as tree height (0.992), basal diameter (0.809), DBH (0.949), crown height (0.963), crown width (0.899) and biomass components. The highest relationship was observed in Tree height (0.992) with above ground biomass followed by crown height (0.963). The above ground biomass had strong relationship with independent variable such as tree height, basal diameter, DBH, crown height and crown width. The highest correlation was registered with tree height followed by crown height. Neem biomass had a highly significant relationship with all the independent variable viz., tree height,

Table 3: Allometric equation for estimating above ground biomass ( $\mathrm{kg} \mathrm{plant}^{-1}$ ) of Neem tree

\begin{tabular}{lcccccccc}
\hline & \multicolumn{7}{c}{ Predicted variable (Above ground biomass) } \\
\hline $\begin{array}{l}\text { Independent variable } \\
\text { (Predictor) }\end{array}$ & $\mathrm{b}$ & $\mathrm{a}$ & $\mathrm{r}$ & $\mathrm{SSE}$ & $\mathrm{R}^{2}$ & $\mathrm{~F}$ cal & Corrected allometric equation \\
\hline Tree height $(\mathrm{m})$ & 4.862 & 0.016 & 0.996 & 0.046 & 0.992 & $842.342^{*}$ & $\mathrm{AGB}=0.016(\mathrm{TrHt})^{4.862}$ \\
Basal diameter $(\mathrm{cm})$ & 1.729 & 0.498 & 0.900 & 1.062 & 0.809 & $29.7340^{*}$ & $\mathrm{AGB}=0.498(\mathrm{BD})^{1.729}$ \\
DBH $(\mathrm{cm})$ & 2.109 & 0.213 & 0.974 & 0.286 & 0.949 & $129.419^{*}$ & $\mathrm{AGB}=0.213(\mathrm{DBH})^{2.109}$ \\
Crown height $(\mathrm{m})$ & 2.599 & 19.63 & 0.981 & 0.205 & 0.963 & $183.094^{*}$ & $\mathrm{AGB}=19.63(\mathrm{Cr} \mathrm{Ht})^{2.599}$ \\
Crown width $(\mathrm{m})$ & 1.326 & 9.235 & 0.948 & 0.562 & 0.899 & $62.3870^{*}$ & $\mathrm{AGB}=9.235(\mathrm{Cr} \mathrm{Wd})^{1.326}$ \\
\hline
\end{tabular}

*: Significant at $(p=0.01)$ level

basal diameter, DBH, crown height and crown width. The regression equation was developed using power model has presented in table 3.

3.3.2. Allometry equation for estimating below ground biomass

The above ground variables (tree height, basal diameter, DBH, crown height and crown width had strong and significant relationship with predicted variable of below ground biomass. The highest correlation was registered with tree height (0.988) followed by crown height (0.974). Crown height and branch biomass as predictor variables, exhibited very strong allometric relationship with below ground biomass in the present investigation. Similar findings were reported that by Shem kuyah et al., 2012. In comparison with the mean values for soft wood species reported by Ruiza-peinado et al. (2011), hard wood species allocate a greater proportion of resource to crown and below ground biomass than to stem (Ruiz-Peinado et al., 2012). Results of the regression relationship of below ground biomass with various growth variables of neem are given in Table 4. Below ground biomass has a highly significant relationship with tree height (0.988), basal diameter (0.837), DBH (0.967), crown height (0.974) and crown width (0.925).

\subsubsection{Allometry equation for estimating total biomass}

The regression relationship of below ground biomass variable with various growth variables of Azadirachta indica has presented in Table 5. The above ground variables (tree height, basal diameter, DBH, crown height and crown width had highly significant relationship with predicted variable of total biomass. There was observed strong and significant linear relationship between total biomass and predictors viz., tree height (0.991), basal diameter (0.820), DBH (0.956), crown height (0.967) and crown width (0.909). The similar findings were supported that the above ground variables have highly significant relationship with tree height and basal diameter. 


\begin{tabular}{|c|c|c|c|c|c|c|c|}
\hline \multicolumn{8}{|c|}{ Predicted variable (Below ground biomass) } \\
\hline $\begin{array}{l}\text { Independent variable } \\
\text { (Predictor) }\end{array}$ & $\mathrm{b}$ & a & r & SSE & $\mathrm{R}^{2}$ & F cal & Corrected allometric equation \\
\hline Tree height (m) & 5.444 & 0.003 & 0.994 & 0.081 & 0.988 & $598.919^{*}$ & $\mathrm{BGB}=0.003(\mathrm{TrHt})^{5.444}$ \\
\hline Basal diameter $(\mathrm{cm})$ & 1.972 & 0.131 & 0.915 & 1.141 & 0.837 & $36.0070^{*}$ & $\mathrm{BGB}=0.131(\mathrm{BD})^{1.972}$ \\
\hline $\mathrm{DBH}(\mathrm{cm})$ & 2.388 & 0.052 & 0.984 & 0.229 & 0.967 & $207.698^{*}$ & $\mathrm{BGB}=0.052(\mathrm{DBH})^{2.388}$ \\
\hline Crown height $(\mathrm{m})$ & 2.930 & 8.790 & 0.987 & 0.185 & 0.974 & $258.218^{*}$ & $\mathrm{BGB}=8.790(\mathrm{Cr} \mathrm{Ht})^{2.930}$ \\
\hline Crown width (m) & 1.508 & 3.686 & 0.962 & 0.526 & 0.925 & $86.3690^{*}$ & $\mathrm{BGB}=3.686(\mathrm{Cr} \mathrm{Wd})^{1.508}$ \\
\hline
\end{tabular}

*: Significant at $(p=0.01)$ level

Table 5: Allometric equation for estimating total biomass ( $\mathrm{kg} \mathrm{plant}^{-1}$ ) (Above ground+below ground biomass) of Neem tree

\begin{tabular}{lccccccc}
\hline & \multicolumn{7}{c}{ Predicted variable (Total Biomass) } \\
\hline $\begin{array}{l}\text { Independent variable } \\
\text { (Predictor) }\end{array}$ & $\mathrm{b}$ & $\mathrm{a}$ & $\mathrm{r}$ & $\mathrm{SSE}$ & $\mathrm{R}^{2}$ & $\mathrm{~F}$ cal & Corrected allometric equation \\
\hline Tree height $(\mathrm{m})$ & 5.057 & 0.017 & 0.996 & 0.051 & 0.991 & $816.472^{*}$ & $\mathrm{~TB}=0.017(\mathrm{TrHt})^{5.057}$ \\
Basal diameter $(\mathrm{cm})$ & 1.810 & 0.604 & 0.905 & 1.088 & 0.820 & $31.8040^{*}$ & $\mathrm{~TB}=0.604(\mathrm{BD})^{1.810}$ \\
DBH $(\mathrm{cm})$ & 2.202 & 0.252 & 0.978 & 0.266 & 0.956 & $151.747^{*}$ & $\mathrm{~TB}=0.252(\mathrm{DBH})^{2.202}$ \\
Crown height $(\mathrm{m})$ & 2.709 & 28.42 & 0.984 & 0.197 & 0.967 & $207.855^{*}$ & $\mathrm{~TB}=28.42(\mathrm{Cr} \mathrm{Ht})^{2.709}$ \\
Crown width $(\mathrm{m})$ & 1.386 & 12.86 & 0.953 & 0.551 & 0.909 & $69.6860^{*}$ & $\mathrm{~TB}=12.86(\mathrm{Cr} \mathrm{Wd})^{1.386}$ \\
\hline
\end{tabular}

*: Significant at $(p=0.01)$ level

This may be because tree height as predictor variable has significant allometric relationship with biomass (Van et al., 2000 and Kumar and Tewari, 1999). Crown depth and crown width, as predictor variables, exhibited very strong allometric relationship with stem biomass in the present investigation. Similar findings were reported in J. curcas (Ghezehei et al., 2009) and Pinus pinea (Correia et al., 2010).

\subsubsection{Allometry equation for estimating total carbon}

The allometric coefficients which were calculated from the allometric relations between the biomass of tree components on total carbon for neem have been presented in table. The highest and strongest coefficient observed between total carbon and tree height (0.991) followed by crown height (0.968) and DBH (0.957). And also the significant relationship was found between the dependent variable (total carbon) and other independent variables viz., basal diameter (0.821), and crown width (0.910). The similar strength has been estabilised in several species, at tree level (Lott et al., 2000, Wang et al., 2000; Samba et al., 2001, and Ghezehei et al., 2009). The relationship between the variables (dependent and independent) had presented in Table 6.

The significant strong non-linear relationship has expressed between predicted variable and predictor, viz., tree height, basal diameter, DBH, crown height and crown width. Generally, the models developed in this study exhibited high coefficient of determination. Equations developed here will be used for validating two-dimensional tree growth and biomass allocation model under similar growing environments, without

\begin{tabular}{lccccccc}
\hline \multicolumn{7}{l}{ Table 6: Allometric equation for estimating Total Carbon content $\left(\mathrm{kg} \mathrm{plant}^{-1}\right)$} & of Neem tree \\
\hline \multicolumn{7}{c}{ Predicted variable (Total Carbon content) } \\
\hline $\begin{array}{l}\text { Independent variable (Pre- } \\
\text { dictor) }\end{array}$ & $\mathrm{b}$ & $\mathrm{a}$ & $\mathrm{r}$ & $\mathrm{SSE}$ & $\mathrm{R}^{2}$ & $\mathrm{~F}$ cal & Corrected allometric equation \\
\hline Tree height (m) & 5.105 & 0.006 & 0.996 & 0.054 & 0.991 & $790.714^{*}$ & $\mathrm{TC}=0.006(\mathrm{TrHt})^{5.105}$ \\
Basal diameter (cm) & 1.829 & 0.232 & 0.906 & 1.100 & 0.821 & $32.1140^{*}$ & $\mathrm{TC}=0.232(\mathrm{BD})^{1.829}$ \\
DBH (cm) & 2.224 & 0.096 & 0.978 & 0.266 & 0.957 & $155.001^{*}$ & $\mathrm{TC}=0.096(\mathrm{DBH})^{2.224}$ \\
Crown height (m) & 2.736 & 11.38 & 0.984 & 0.196 & 0.968 & $212.678^{*}$ & $\mathrm{TC}=11.38(\mathrm{Cr} \mathrm{Ht})^{2.736}$ \\
Crown width (m) & 1.400 & 5.110 & 0.954 & 0.554 & 0.910 & $70.7290^{*}$ & $\mathrm{TC}=5.110(\mathrm{Cr} \mathrm{Wd})^{1.400}$ \\
\hline
\end{tabular}

*: Significant at $(p=0.01)$ level 
the need for destructive sampling. With the help of carbon content of tree biomass, which is assumed to be a fixed proportion of the biomass or determined directly (Kraenzel et al., 2003), they can be used to estimate carbon storage in trees and plantations (Losi et al., 2003) and their wood foliage (Spect and West, 2003).

\section{Conclusion}

Some allometric relationships were developed for neem to predict total biomass and carbon using tree height, $\mathrm{DBH}$, Crown height and crown width as a predictor. The allometric relationship between the variables in Azadirachta indica was highly significant and positive and high correlation. It may be concluded that this study will be helpful in predicting the amount of total biomass and carbon of other neem trees and plantations under dryland condition.

\section{Acknowledgement}

We express our gratitude to Director, Central Arid Zone Research Institute, Jodhpur and Central Research Institute for Dryland Agriculture (CRIDA), Hyderabad for their support and encouragement. We would like to thank to Scientists, technical officers, SRF, JRF, field workers of CRIDA for their cooperation, support and assistance in field and lab during the study.

\section{References}

Achten, W.M.J., Maes, W.H., Reubens, B., Mathijs, E., Singh, V.P., Verchot, L., Muys, B., 2010. Biomass production and allocation in Jatropha curcas L. seedlings under different levels of drought stress. Biomass and Bioenergy 34(5), 667-676.

Anonymous., 1985. The wealth of India - Raw materials. Publication and Information Directorate, CSIR, New Delhi, India.

Anonymous., 2006. Neem - Growing neem, organic farming, health, animal health, environmental use, home uses, economic potential, patents, newbazaars, research papers, world neem conference. Neem foundation (Internet) Mumbai, India - [cited 2006 Jun 20].

Chambers, J.Q., Dos Santos, J., Ribeiro, R.J., Higuchi, N., 2001. Tree damage, allometric relationships, and aboveground net primary production in central Amazon forest. Forest Ecology and Management 152, 73-84.

Chari, M.S., 1996. Neem and transfer of technology. In: Neem and Environment (Vol. I), (Singh, R.P., Chari, M.S., Raheja, K., et al., eds.). Oxford and IBH publishing Co. Pvt. Ltd., New Delhi, India.

Correia, A.C., Tome, M., Pacheco, C.A., Faias, S., Dias. A.C., Freire, J., Carvalho, P.O., Pereira, J.S., 2010. Biomass allometry and carbon factors for a Mediterranean pine (Pinus pinea L.) in Portugal. Forest Systems 19(3), 418433.
Ghezehei, S.B., Annandale, J.G., Everson, C.S., 2009. Shoot allometry of Jatropha curcas. Southern Forest 71(4), 279-286.

Gnana Mathuram, A., 2009. Assessing the carbon sequestration potential of Eucalyptus plantation and its effect on soil ecology. M.Sc. Thesis, Tamil Nadu Agricultural University, Coimbatore.

Girish, K., Shankara Bhat, S., 2008. Neem - A Green Treasure. Electronic Journal of Biology 4(3), 102-111.

Hegde, N.G., 1995. Neem and small farmers- constraints at grass root level. Indian Forester 121, 1040-1048.

Heriansyah, I., Miyakuni, K., Kato, T., Kiyono, Y., Kanazawa. Y., 2007. Growth characteristics and biomass accumulations of Acacia mangium Under Different Management Practices in Indonesia. Journal of Tropical Forest Science 19(4), 226-235.

Ketterings, Q.M., Coe, R., Van Noordwijk, M., Ambagau, Y., Palm, C.A., 2001. Reducing uncertainity in the use of allometric biomass equations for predicting above ground tree biomass in mixed secondary forests. Forest Ecology and Management 146(1), 199-209.

Kraenzel, M., Castillo, A., Moore, T., Potvin, C., 2003. Carbon storage of harvest-age teak (Tectona grandis) plantations, Panama. Forest ecology and management 173(1-3), 213-225.

Kumar, V.S.K., Tewari, V. P., 1999. Aboveground biomass tables for Azadrachta indica. Juss. Int. For. Rev. 1(2), 109-111.

Lodhiyal, L.S., Singh, R.P., Rana, B.S., 1992. Biomass and productivity in an age series of short rotation Populusdeltoides plantations. Trop. Ecol. 33(2), 214-222.

Losi, C.J., Siccama, R. Condit,T.G., Morales, J.E., 2003. Analysis of alternative methods for estimating carbon stock in young tropical plantations. Forest Ecology and Management 184(1-3), 355-368.

Lott, J.E., Howard, S.B., Black, C.R., Ong, C.K., 2000. Allometric estimation of above-ground biomass and leaf area in managed Grevillea robusta agroforestry systems. Agrofor Syst. 49, 1-15.

Montagnini, F., Porras, C., 1998. Evaluating the role of plantations as carbon sinks: an example of an integrative approach from the humid tropics. Environmental Management 22, 459-470.

Noor mohamed, M.B., Rajeshwar Rao, G., Sharat Kumar, P., Satty Reddy, P., 2016. Allometric equations for predicting biomass and carbon of Simarouba glauca plantations in dryland of Hyderabad, Telangana. Indian Journal of Agricultural Sciences 86 (11), 1477-1481

Roxburgh, W., 1874. Description of Indian plants. Today and tomorrow's Printers and Publishers, New Delhi, India.

Ruiz-Peinado, R., Montero, G., Rio, M., 2012. Biomass models to estimate carbon stocks for hardwood tree species. 
Forest system 21(1), 42-54.

Ruiz-Peinado, R., Rio, M., Montero, 2011. New models for estimating the carbon sink capacity of Spanish softwood species. Forest system 20, 176-188.

Specht, A., West, P.W., 2003. Estimation of sequestered carbon on farm forest plantation in northern New South Wales, Australia. Biomass Bioenergy 25, 363-379.

Tewari, D.N., 1992. Monograph of neem (Azadirachta indica A. Juss.). International Book Distributors, Dehra Dun, India.

Uma, M., Rajendran, K., Kuru, S., 2011. Biomass and carbon sequestration potential of Casuarina equisetifolia in farm forestry plantation of east coast in south Tamil Nadu, India. Plant Archives 119, 957-963.

Van, T.K., Rayachhetry, M.B., Centre, D., 2000. Estimating aboveground biomass of Melaleuca quinquenenervia in Florida, USA. J Aqua Plant Manag 38, 62-67.

Wang, J.R., Letchford, T., Comeau, PandKimmins, J.P., 2000. Above and below ground biomass and nutrient distribution of a paper birch and sub alpine fir mixed species stand in the sub-boreal spruce zone of British Columbia. For. Ecol. Manage. 130, 17-26. 